\title{
Does Current Dietary Pattern Ensure Nutritional Security in India?
}

\author{
Malaiarasan Umanath ${ }^{1 *}$, Balasubramanian $\mathbf{M}^{2}$ and Paramasivam $\mathbf{R}^{1}$ \\ ${ }^{1}$ Assistant Professor, Madras Institute of Development Studies, Chennai, India, \\ ${ }^{2}$ Assistant Professor, Institute for Social and Economic Change, Bangalore, India
}

ISSN: 2640-9208

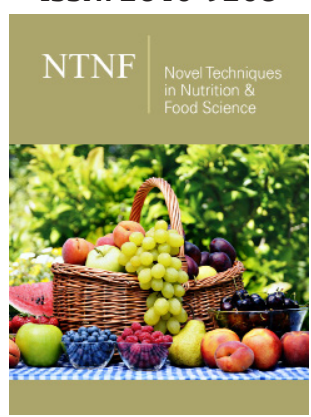

${ }^{* 1}$ Corresponding author: Malairasan Umanath, Assistant Professor, MIDS, Chennai

Submission: 覀 April 28, 2019

Published: 眥 May 28, 2019

Volume 3 - Issue 5

How to cite this article: Malaiarasan $\mathrm{U}$, Balasubramanian $\mathrm{M}$, Paramasivam R. Does Current Dietary Pattern Ensure Nutritional Security in India?. Nov Tech Nutri Food Sci. 3(5).NTNF.000575.2019. DOI: 10.31031/NTNF.2019.03.000575

Copyright@ Malaiarasan Umanath, This article is distributed under the terms of the Creative Commons Attribution 4.0 International License, which permits unrestricted use and redistribution provided that the original author and source are credited.

\section{Opinion}

Science and technological developments have increased food production manifold over fifty years in many developing countries including India. Also, $21^{\text {st }}$ centuries' major policy breakthrough is liberalization and globalization which made the easy accessibility of food products from any parts of the World. However, the challenge of malnutrition remains a major development concern across world and affected sustainable development of nations in different ways. India is in serious stage with respect to global hunger index with the score of 31.3, which is more than the other south Asian countries such as Sri Lanka, Nepal and Bangladesh. In practical, people are so vulnerable to access food due to many reasons and this vulnerability to command necessary food has created great space between food and people. This space can be filled by ensuring food availability, accessibility and affordability. Although there is an increased trend in the intake of pulses, oils, fats and vegetables by the child in the country, there exists still a 30 percent gap in the actual and the recommended dietary energy intake of people living [1], while the per capita income has increased almost 1,400 times in 2016. The latest Phyto-nutrient report indicated that the younger generation consumes less nutritious food than elder people [2]. The federal policy thinks tank NITI Aayog and the UN released a report on December 2018 reveals that Himachal Pradesh, Kerala and Tamil Nadu states have gained significant scores to achieve no poverty and no inequality. For instance, Tamil Nadu has secured a score points of 68 as the state has taken a various supportive measure for poverty reduction and for good health and well-being.

The country has been producing fairly good quality of fruits and vegetables with the annual production of around 88 and 162 tons of each one, respectively. Despite second world largest producer of fruits and vegetables, India's consumption is less than the recommended quantity of 400 grams $[2,3]$. The lower intake of fruits and vegetables is largely determined by dietary choice of individuals in India, which is skewed towards cereals. Low fruit and vegetable intake are estimated to cause about $31 \%$ of ischemic heart disease and $11 \%$ of stroke worldwide. In addition, there was decline in intake of milk and milk products and in overall calorie consumption specifically in households with children aged below 3 years [4]. Low intake of nutrient-rich foods affects children's future productivity negatively [5]. Singh [6] observed that dietary pattern and intake level of food among the children in tribal area of Bihar is poor. There was a high level of malnutrition among child in tribal area of Madhya Pradesh due to lesser period of breastfeeding, delayed initiation of supplementary nutrition, and implementation of poor growth monitoring and poor implementation of malnutrition reduction interventions [1]. Mwangome et al. [7] find out that gender inequality, presence or absence of support networks, alternative explanatory models of malnutrition, and poverty were the couple of important drivers that possibly affect the ability of a mother to follow dietary choice in pregnancy period. Also, people living in the urban areas follow completely different dietary pattern from those counterparts of rural people [8].

Malnutrition problem and its associated diseases can be reduced only when the people follow the recommended dietary patterns, including an adequate intake of fruits and vegetables. A diet high in fruits and vegetables is associated with a decreased risk of 
serious chronic diseases, including some types of cancer and cardiovascular disease $[9,10]$. A healthy diet inclusive of fruits and vegetables is important for optimal child growth, weight management, and chronic disease prevention [11]. Overall it is estimated that up to 2.7 million lives could potentially be saved each year if fruit and vegetable consumption was sufficiently increased [12]. Similarly, intake of adequate millets could possibly protect diabetes as the crops contains high level of proteins, minerals, vitamins, antioxidants, non-glutinous and non-acid forming, higher levels of low Glycemic Index (GI), non-starch polysaccharides and dietary fibers $[13,14]$. Livestock products are, particularly fish and milk, rich in protein [7]. Also, these possess richer content of amino acids, unsaturated fatty acids, vitamins, and trace metals and more importantly it is easily digestible $[15,16]$. Consumption of fish helps to prevent of cardiovascular diseases, high blood pressure, cholesterol, Alzheimer's disease, and cancer to the humans $[17,18]$. Moreover, fish has low cholesterol over red meat and is recommended for both the young and the old [19].

The other side of the malnutrition problem is over-nutrition. One in nine schoolchildren suffering from over-nutrition is a concern as India suffers a dual burden of undernutrition and overnutrition, representing the inequitable distribution of health [20]. Southern states like Tamil Nadu and Andhra Pradesh have higher ration of obesity problems as compared to other states [21]. As the economy grows upward, the quality of food in terms of nutrients such as saturated and trans fats, sugar and salt which are the major contributor to overweight and obesity problems and consequently development of non-communicable diseases [22]. Also, we can also observe the habit of consuming processed food in high volume, irrespective of income categories and living regions. Hunger and malnutrition including obesity problem have remained a global development challenge. These affect sustainable development of nations in multiple aspects.

Children are the foremost auspicious assets to parents and the nations. Inclusion of proper nutrient in the scheduled time is good for better health. Intake of adequate level of protein, carbohydrate, fat, vitamins and less cholesterol content of food in childhood (age under 5) would support for remaining life period. It is noted from the recent household surveys that intake of diet by the child has been changing from low value nutrients to high value nutrients such as readily available food stuffs such as processed food items of biscuits, chocolates, ice creams; rice items of muri, buffed rice; wheat products of Maida, bread; cow milk and meat items; preserved fruits and vegetables. The report of National Institute of Nutrition recommends an individual should take minimum of 300 grams of vegetables per day including 50grams from green leafy vegetables, 200 grams of other vegetables and 50 grams of tubers. Apart from this, 100grams of fresh fruits should be consumed daily per person. This type of nutrients rich food consumption during age period of 0-5 years helps to strengthen physical and knowledge level and, more importantly, overcome malnutrition problem, which is major challenging thematic area of Sustainable Development Goal (SDG) envision 2030 Goal of 1) No poverty; and 2) Zero hunger.

Food security exists when all people, at time, have physical, social and economic access to enough, safe and nutritious food which meets their dietary needs and food preferences for an active and healthy life [23]. Significant amount of literature can be found on the linkage of nutritional status, dietary diversity with food availability and accessibility. Only limited studies have tried to establish the link between affordability of consumers and diet and nutritional diversity. Even, there is no research is undertaken to analyze the dietary diversity pattern among children in India as children are the most vulnerable to poor dietary diversity which causes malnutrition, micronutrient deficiency and its associated disease and disorders such as scurvy, anemia, blindness, diarrhea, respiratory illness, infectious diseases-and consequent problems of growth retardation, impaired cognitive development, poor school performance, etc.

\section{References}

1. Mishra CP (2017) Malnutrition-free India: Dream or reality. Indian J Public Health 61(3): 155-162.

2. Mukherjee, Arpita, Dutta, Souvik, Goyal, et al. (2016) India's phytonutrient report: A Snapshot of fruits and vegetables consumption, availability and implications for phytonutrient intake. Indian Council for Research on International Economic Relations (ICRIER), New Delhi, India.

3. Danaei G, Hoorn SV, Lopez AD, Murray CJ, Ezzati M (2005) Causes of cancer in the world: comparative risk assessment of nine behavioral and environmental risk factors. Lancet 366(9499): 1784-1793.

4. Maitra P, Rammohan A, Ray R, Robitaille MC (2013) Food consumption patterns and malnourished Indian children: Is there a link? Food Policy 38: 70-81.

5. Strauss J, Thomas D (1995) Human resources: Empirical modeling of household and family decisions. In: $\left(1^{\text {st }}\right.$ edn), Handbook of development economics 3: 1883-2023.

6. Yadav RJ, Singh P (1999) Nutritional status and dietary intake in tribal children of Bihar. Indian Pediatr 36(1): 37-42.

7. Adeniyi OR, Alabi OM, Ademosun AA (2010) Market prices and proximate composition of four common sources of animal protein in south-western Nigeria. International Journal of Current Research 11(9): 97-99.

8. Popkin BM (1999) Urbanization, lifestyle changes and the nutrition transition. World development 27(11): 1905-1916.

9. WHO (2005) Preventing chronic diseases: A vital investment? World Health Organization.

10. WHO (2003) Diet, nutrition and the prevention of chronic diseases: report of a joint WHO/FAO expert consultation? World Health Organization 916

11. USDA U (2010) Dietary guidelines for Americans 2010. US Government Printing Office, USA.

12. WHO (2002) The world health report 2002: reducing risks, promoting healthy life? World Health Report.

13. Sakamoto S (1982) Waxy endosperm and perisperm of cereals and grain amaranth and their geographical distribution. Journal of the Japanese Society of Starch Science 29(1): 41-55.

14. Muthamilarasan M, Dhaka A, Yadav R, Prasad M (2015) Exploration of millet models for developing nutrient rich Graminaceous crops. Plant Sci 242: 89-97.

15. Burger J, Stephens WL, Boring CS, Kuklinski M, Gibbons JW, et al. (1999) Factors in exposure assessment: ethnic and socioeconomic differences in fishing and consumption of fish caught along the savannah river. Risk Anal 19(3): 427-438.

16. Kizilaslan H, Nalinci S (2013) The fish meat consumption habits of households and the factors affecting their fish meat consumption in the province of amasya. Gazi Bilim Aras Dergisi 5: 61-75. 
17. Kornitzer M (2001) Adult fish and health. In: Descheemaeker K, Provoost CA (Eds.), Impact of nutrition on health-Recent developments-4, Garant, pp. 53-65.

18. Naughton SA, Ball K, Mishra GD, Crawford DA (2008) Dietary patterns of adolescents and risk of obesity and hypertension. The Journal of Nutrition 138(2): 364-370.

19. Eyo AA (2002) Fish processing in the tropics. Published by National Institute for Fresh Water Fisheries Research (NIFER), pp. 1-4.

20. Jena PK, Jeena BP (2018) Overnutrition among schoolchildren in India: a review and meta-analysis. The Lancet Global Health 6(S25).
21. Singla P, Sachdeva R, Kochhar A (2012) Effect of nutrition counselling on junk food intake and anthropometric profile among adolescent girls of working mothers. International Journal of Scientific and Research Publications 2(5): 1-7.

22. Babu S, Gajanan SN, Hallam JA (2016) Nutrition economics: Principles and policy applications. Academic Press, USA.

23. Food and Agriculture Organization of the United Nations (1996) Rome declaration on world food security and world food summit plan of action. World Food Summit, Rome, Italy, pp. 13-17. 